\title{
THE LATE MIDDLE KINGDOM STELA OF THE DISTRICT OFFICIAL PESESH
}

\author{
Faheed, H. \\ Lecturer Department of Egyptology, Faculty of Arts, Sohag University, Egypt \\ Faheedahmed@yahoo.co
}

\begin{abstract}
This article deals with a sandstone funerary stela from Qadaya-magazine at Karnak. It belongs to the District Official Pesesh. The stela was found at Rizeikat and measures $69 \mathrm{~cm}$ high and 42 $\mathrm{cm}$ width. The inscriptions contain some interesting features in the orthograph of the epithets and offering formulae. On the basis of stylistic features, the stela can be dated to the late Middle Kingdom.
\end{abstract}

Keywords: District official Pesesh, Rounded-topped stela, Late Middle Kingdom, Sobek-hotep

\section{Introduction}

This stela, made of sandstone, measures $69 \mathrm{~cm}$ high and $42 \mathrm{~cm}$ width. It is now in the Karnak Qadaya-magazine", and its provenance might be SumenuRizeikat [1]. The central part, has been damaged. With its back left uneven, the round- topped stela has a well-prepared surface, the decoration of which is

\section{Description}

As shown in fig. \& pl. (1) The central part of this rounded-topped stela (a) has been damaged and its back left uneven. The stela has a well-prepared surface, the decoration is framed by an incised line. Thematically the stela is divided into three parts; the upper part is devoted to two $w \underline{d} 3 t$-eyes flanking a $\check{s} n$ ring $^{(b)}$, the second one is reserved for a four-lines offering formula ${ }^{(\mathrm{c})}$, while the lower part is decorated with three registers of standing figures. The framed by an incised line. Thematically divided into three parts; the upper part is devoted to two $w d \underline{d} 3$-eyes flanking a $\check{s} n$ ring, the second one is reserved for a four-line offering formula while lower part is decorated with three registers of standing figures. The representations and inscriptions are incised.

representations and inscriptions are incised. All the fifteen figures in the three registers below the offering text are depicted standing, on the left half always two persons, on the right half three. The top register shows a man and a woman facing right and three men facing left. In the middle register all five persons are women, while the lowermost register has two women on the left side and a woman and two men on the right side ${ }^{(d)}$. All women are dressed in long tight fitting 
garments, each with one shoulder strap, and wear long tripartite wigs and necklaces. The men are dressed in short kilts with a large triangular, and wear short wigs. All male and female figures have their left arms hanging by their sides, and the right hands resting on their breasts. $^{(\mathrm{e})}$
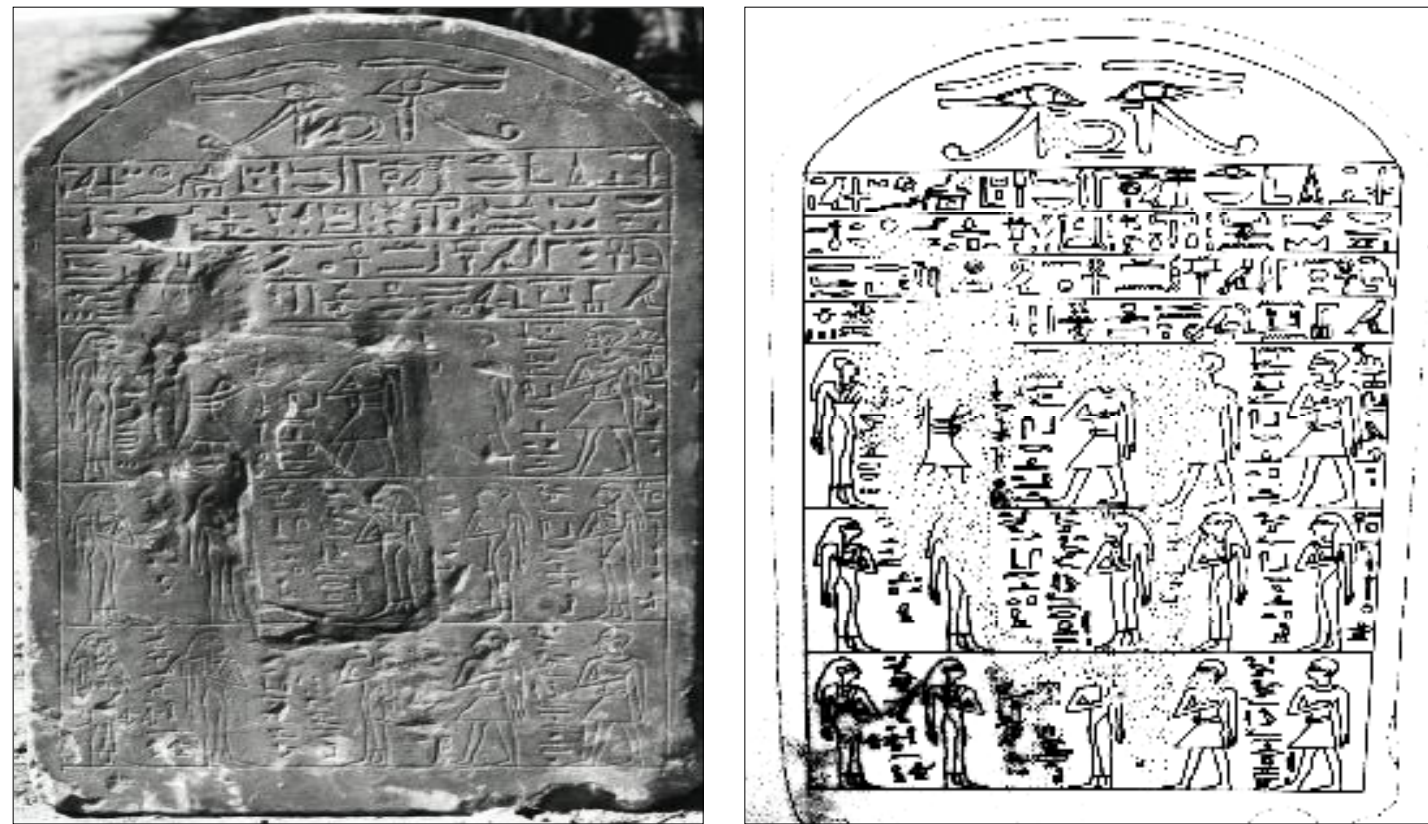

Figure $\&$ plate (1) the late middle kingdom stela of the district official

\section{Inscriptions}

The inscriptions of the middle part of the stela runs from right to left, including the offering formula

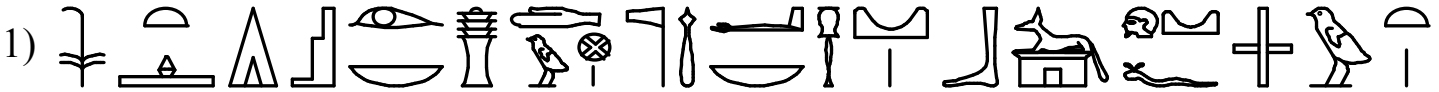

2)

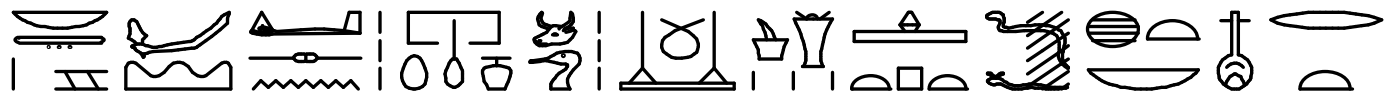

3)

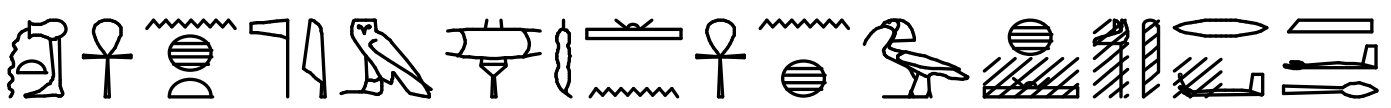

4)

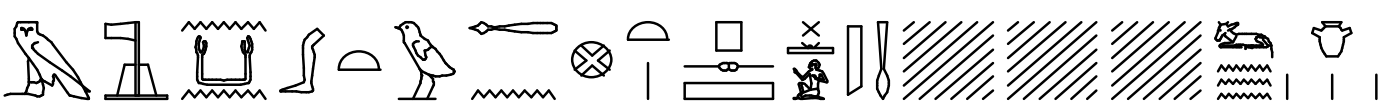

(1) htp di nsw (n) Wsir nb Ddw ntr 3 nb 3bdw Inpw tpy $\underline{d} w$.f imy-wt (2) nb T3-dsr

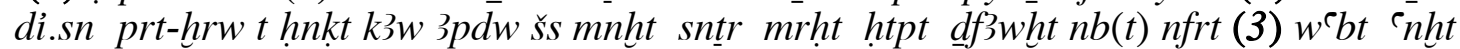

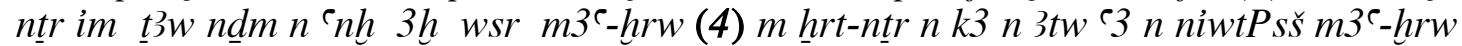
[s3 n.......ms $n$ ] Iwh-Ibw

(1) An offering which the king gives $^{(\mathrm{f})}$ to Osiris ${ }^{(\mathrm{g})}$, lord of Busiris ${ }^{(\mathrm{h})}$, the great $^{(\mathrm{I})}$ god, lord of $\mathrm{Abydos}^{(\mathrm{J})}$, (and to) Anubis, who is upon his mountain, the embalmer, who is in $^{(\mathrm{k})}$ the embalming place $^{(1)},(2)$ Lord of the sacred land ${ }^{(\mathrm{m})}$, that they may give invocation-offerings, consisting of beer, ox, fowl, alabaster, clothing, incense, unguents, offerings, provisions, and every good and (3) Pure ${ }^{(\mathrm{n})}$ thing, by which the god lives, the pleasant breath of life, usefulness, and power. The justified $^{(0)}$ (4) in the necropolis ${ }^{(p)}$, for the ka of a district official ${ }^{(\mathrm{q})}$ Pesesh $^{(\mathrm{r})}$, justified $^{(s)} \quad$ the son of.....born of] Iuh$\mathrm{Ibw}^{(\mathrm{t})}$. 
The inscriptions of the $1^{\text {st }}$ register below the offering text runs from left to right, including names and titles of the figure

(1) First man looking left, hieroglyphs in front of him (first five signs are destroyed!):

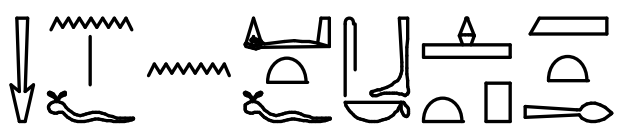

sn.f $n$ mwt.f sbk-htp m3r.t-hrw

"His brother, (born) of his mother, Sobek-hotep, justified"

(2) Second man looking left, the hieroglyphs behind him: (a part of the figure is lost):

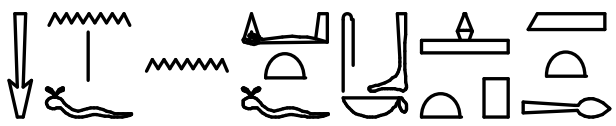

sn.f $n$ mwt.f sbk-htp $m 3^{\ulcorner} . t-h r w$

"His brother, (born) of his mother Sobek-hotep, justified"

(3) Third man looking left, the hieroglyphs with titles and name behind him:

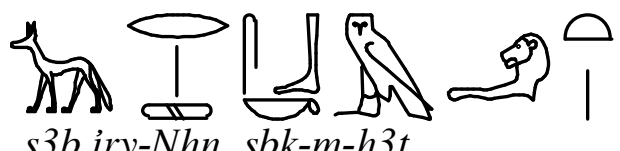

s3b iry-Nhn, sbk-m-h3t

"The dignitary, guardian of Nekhen ${ }^{\text {(u) }}$ Sobek-em-hat"

(4) The first figure looking right: This figure of a man and his name are damaged.

(5) The second figure looking right: This figure of the woman is completed but the inscription in front of her is damaged.

The inscriptions of the $2^{\text {nd }}$ register runs from left to right and accompanies five female figures:

(1) First woman looking left, the hieroglyphs before her:

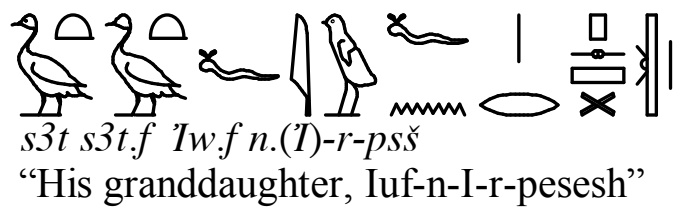

(2) Second woman looking left, the hieroglyphs behind her:

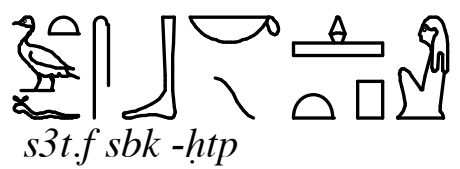

"His daughter, Sobek-hotep"

(3) Third woman, looking left, the hieroglyphs behind her:

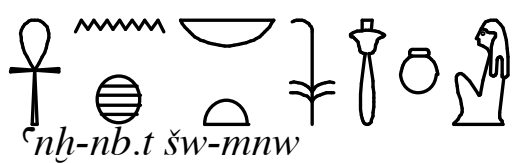

"Ankh-nebt Su-menu"(v).

Is the $t$ under nb really there? The determinative at the end is A1, not $\mathrm{B} 1$, then the reading of the name could be understand as: "The Lord of Sumenu may live"

(4) The first woman looking right (upper part is damaged), the hieroglyphs before her:

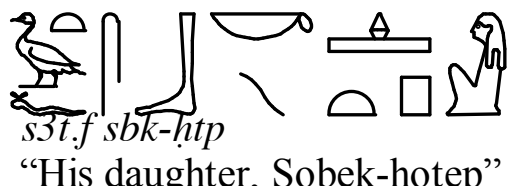


(5) The second woman looking right, the hieroglyphs before her:

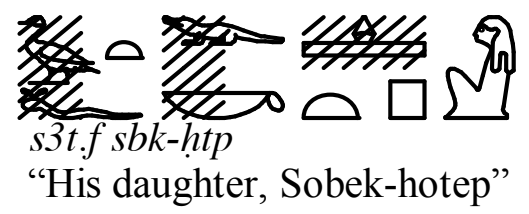

The inscriptions of the last register runs from left to right, and
inscribed two men and five women:

(1) First figure looking left: a woman with hieroglyphs before her, partly damaged at the beginning:

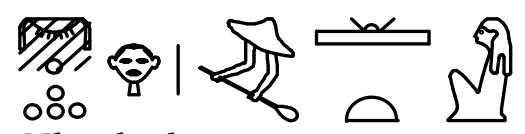

Nbw-hr-hnnyt

"Nebu-her-khenyt", (w)

(2) Second figure looking left: a man, the text before him is damaged.

(3) Third figure looking left: a man with the hieroglyphs before him:

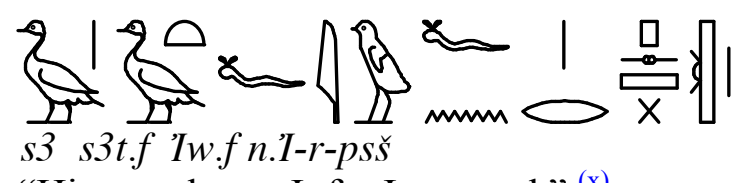

"His grand-son, Iuf-n.I-r-pesesh" (x)

(4) First figure looking right: a woman with the hieroglyphs before her:

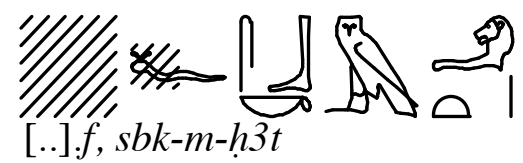

"His [...], Sobek-em-hat"

(5) Second figure looking right: a woman with the hieroglyphs before her:

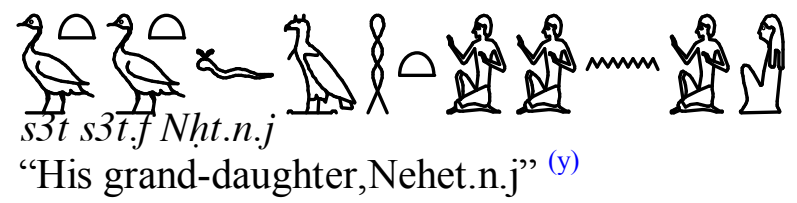

\section{Dating}

The stela can be dated to the late Middle Kingdom based on different characteristical features. Stylistically, the lower parts of many stelae of the late Twelfth Dynasty or the beginning of Thirteenth Dynasty are divided into many registers depicting members of the owner's family every one inside a frame [2]. Paleographically, the writing of the place names $\underline{d} d w, 3 b \underline{d} w$ is particular for this period as well as the use of the epithet $m 3{ }^{r} t$-hrww. Prosopographically, the names of the owner and his family are

also characteristic of the late Middle Kingdom, defined as the period from the reign of Senwosret III to the late Thirteenth Dynasty, particularly the names [3]. of the owner and his family (Pš̌ , Nhty , Nbw-hr-hnyt, 'Iw.f n.I-r-psš) [4]. Textual constructions like a similar offering formula of $h t p d j n s w$, the kinds of offerings and the phrase htp.w df3.w ht $n b t$ nfrt $w^{c} b t$ ' $n h t j$ ntr jm are attested on some stelae from the late Twelfth Dynasty to the mid-Thirteenth Dynasty [5]. 


\section{Conclusion}

The stela is datable from its offering formula, design, layout, inscription, and the general shape of the stela , the appearance of the figures to the late Middle Kingdom.

\section{Endnotes}

(a) Stelae with a rounded lunette are documented through the Eleventh Dynasty, see: H.W. Müller, "Die Totengedenksteine des Mittleren Reiches, ihre Genesis, ihre Darstellungen und ihre Komposition", in: MDAIK 4, 1933, 186-187. The arch of the stela probably imitates the vaults of burial chambers in Upper Egyptian rock-cut tombs and/or symbolizes the heaven and the central solar path that the deceased must traverse, see: $R$. Hölzl, Round-Topped Stelae from the Middle Kingdom to the Late Period. Some Remarks on the Decoration of the Lunettes, in: Sesto Congresso Internazionale di Egittologia: Atti $I$, Turin 1992, 285.

(b) For the udjat eye and shen ring during the Twelfth Dynasty reign of Senwosret III on a false door in Cairo Museum see: $C G C$ 20686; and for Louvre Mus. No. C7 see Gayet, Stèles, pl. 6: cartouches of Amenemhat III and IV. In both cases the stela is rectangular. The pair of $w d 3 t$-eyes is found in the lunette of a round-topped stela referring to the twenty-fifth year of Amenemhat III and probably to be dated accordingly (Berlin 1198; Äg. Inschr I, 176-177). A concise but comprehensive description of the type of the stela under discussion is presented by Hayes, Scepter of Egypt I, 345-346, where all the examples given are assumed to belong to the Thirteenth Dynasty; H.G. Evers, Staat aus dem Stein II, München 1929, 566; and on some stelae see H.W. Müller, in: MDAIK 4, 1933, 197; See also R. Engelbach, Steles and tables of offerings of the late Middle Kingdom from Tell Edfu in: $A S A E$ 22, 1927, 113138; A.O. Bolshakov/S.G. Quirke, The Middle Kingdom Stelae in the Hermitage III, Paris 1999, 36; H.G. Fischer/R.A. Caminos, Ancient Egyptian Epigraphy and Paleography, New York 1976.

(c) Stelae with four lines (long offering formula) of inscription for example see

W.K. Simpson, The Terrace of the Great God at Abydos: The Offering Chapels of Dynasties 12 and 13, New Haven and Philadelphia 1974: ANOC 63.2 Stuttgart SP No. 3;ANOC 63.1 Oxford Q.C. 1111, pl. 84. Also see Smither/Dakin, in: JEA 25, 1939, 157165. The first stela is inscribed with an Anubis animal in the upper part and the second one with $m w$-sign. Both stelae are dated to Thirteenth Dynasty. Stelae with $\check{n} n$-ring and two or three lines of inscription (short offering formula) are dated to end of Twelfth Dynasty, see for example CGC 20055, 20140.

(d) The lower part of many stelae including three registers of the family members are represented in sitting position are dated to end of Twelfth Dynasty/beginning of Thirteenth Dynasty. See CG 20055; W.K. Simpson, Terrace, ANOC 63.1, 63.2, pl.84 respectively. Family members represented in standing position in three registers are dated to beginning of Thirteenth Dynasty, see: Cairo JE 42824.

(e) For this attitude see: B. Dominicus, Gesten und Gebärden in Darstellungen des Alten und Mittleren Reiches, SAGA 10, Heidelberg 1994, 5-9 (no.7), fig. 1 (7:1)

(f) This writing of the $h t p-d i-n s w$ formula is the most common found on the monuments of the Middle Kingdom. Osiris written without a determinative see, Bennett, JEA 27,27-8, and with a stroke under the eye, suggests a late Middle kingdom date. For the same writing see, e.g. Stelae Rio de Janeiro2435, Bologna ks 1904, Stuttgart no.II, Vienna KHM AS III,152 and 160, all from the time of Amenemhat III or later. The offering formula isattested on many stelae without Anubis, see W.K. Simpson, Terrace, ANOC 26.2 BM 247 is dated to Twelfth Dynasty (temp. Amenemhat III); Hier. Texts III, pl. 25. The formula of htp dj nswt with Osiris and Anubis in 
two different directions on the false door-stela of Leiden V, 5 see ibid., ANOC 23.2, pl. 34; W. Barta, Aufbau und Bedeutung der altägyptischen Opferformel, ÄF 24,1968, 52-56; C.J.C. Bennett, Growth of the htp-di-nsw Formula in the Middle Kingdom, in: JEA 27, 1941, 77-82; P.C. Smither, The Writing of htp-di-nsw in the Middle and New Kingdoms, in: JEA 25, 1939, 34-37.

(g) The writing of Osiris without the divine determinative is standard on many stelae of the late Twelfth and Thirteenth Dynasties at Abydos, see W.K. Simpson, Terrace, for example ANOC 44, pl. 11.

(h) The writing of $\underline{D} d w$ is mentioned here with the city-sign. For a similar writing, see W.K. Simpson, Terrace, ANOC 4.3, CGC 20542 (dated to Senwosret III). For the complete series of epithets attributed to Osiris at the beginning of the XII ${ }^{\text {th }}$ Dynasty: Wsir $n b \underline{D} d w$ ntr 3 $n b 3 b d \underline{d}$, see: H. Satzinger, "Die Abydos stele des Ipw aus dem Mittleren Reich", in: MDAIK25, 1969, 125; for the spelling of $D d w^{\prime \prime B u s i r i s " ~ a s ~ a ~ p a r t ~ o f ~ t h e ~ O s i r i s ~}$ epithet $n b \underline{D} d w$, see C.J.C. Bennett," Growth of the htp-di-nsw Formula in the Middle Kingdom, JEA 27,1941,78.

(i) For $n t r$ C 3 referring to Osiris, see most recently H.G. Fischer, "Marginalia II" GM 128,1992,72-5; The vertical arrangement of 33 -sing in $n t r ~ 3 ~ n b ~ p t$ points to the early Middle Kingdom see W. Schenkel, Frühmittelägyptische, Studien BOS13; Bonn, 1962, 4b; the" later" horizontal arrangement of the 3 sing within the sequence of the Osiris epithets is already attested at the end of the reign of Mentuhotep II, see J. Allen," Some Theban officials of the Early Middle Kingdom,in Der Manuelian (ed.), Studies Simpson, I, 10n.43; We should note, 3 is written both with wooden column-sign and arm-sign. Similar writing is to be found on two stelae of Thirteenth Dynasty from Abydos, see JE 42824; W.K. Simpson, Terrace, ANOC 49.2 Avignon-Calvet 3.

(j) The name of $3 b \underline{d} w$ is mentioned without the determinative of city, for further examples see: W.K. Simpson, Terrace,
ANOC 58.1, 2, Louvre C11, C12. The use of the epithets of Osiris points to a date in the Middle Kingdom: J. Yoyotte, Les pélérinages dans l'Egypte ancienne, in: Sources Orientales III, 1960, 35-36. But the writing of htp dj $n s w$ dates the stela earlier than the Second Intermediate Period: C. Bennet, The Writing of htp $d j$ $n s w$ Formula in the Middle Kingdom, in: JEA 25, 1941, 77-82; This sequence of epithets Wsir $n b \underline{D} d w \quad n t r$ c3 $n b 3 b d w$ is the most frequent on the Abydos stelae .For the range and frequency of the sequences of epithets on Abydos stelae see, J.Spiegel," Die Gotter von Abydos" GOF iv,7; Wiesbaden,1973,173-5.

(k) Imy $\&$ without $\triangle$ is known from many stelae of the FIP and from the Thinite Cemetery. For example see R. Leprohon, Stelae I, Boston MFA 12.1479, stela of W3d-stj from Mesheikh tomb No. 101 (dating to FIP); MFA 12. 1478 from Mesheikh tomb No. 2109, stela of $h n j j$ dating to FIP; MFA 12.1476 stela of $R h$ wj from Mesheikh tomb No. 123 dating to FIP; MFA 25. 626 stela of $J m 3$ from Sheikh Farag tomb No. 509 dating to FIP; MFA 25. 627 stela of $J j j$; from Sheikh Farag dating to FIP; MFA 25.671 stela of $J n$-hrt-nht from Sheikh Farag tomb No. 524 dating to FIP; MFA stela of $K n j$ from Sheikh Farag tomb No. 5038 dating to FIP; MFA 25.679 from Sheikh Farag debris above cemetery 4000 dating to FIP. For some examples from other nomes see Boston MFA 04.1851 stela of Jtjj from Thebes dating to the Ninth Dynasty, Boston MFA 03.1848 stela of Mnw from Gebelein dating to Ninth to Tenth Dynasty; Boston MFA 98.1050 stela of snt thj from Dendera dating to late FIP or Eleventh Dynasty; Boston MFA 98-1031 stela of $B b j$ from Dendera Sixth or Eighth Dynasty. See also Y. El Masry, An Unfinished Stela of the Earliest Heracleopolitan Period, in: $B S E G$ 27, 2006, 61-73; id., in: Egyptian Journal of Tourism Studies 4, no.1-2, 2005, 121131, fig. 1.

(1) $W t$ is written without the determinative of the city. For $w t$ in the epithet jmj wt of Anubis in the Old and Middle Kingdom see W. Schenkel, Frühmittelägyptische Studien, 1962, 40, 107.

(m) A rare writing on an example from Abydos see W.K. Simpson, Terrace, ANOC 50.1, CG 20556; a similar 
formula is cited on a stela of $J m 3 . j$ from Sheikh Farag Tomb No. 509 and dated to First Intermediate Period, see R.G. Leprohon, Stelae I: The Early Dynastic Period to the Late Middle Kingdom, Boston MFA 25.626; stela of Jn-hrt-hk3, see D. Dunham, Naga-edDeir stelae of the First Intermediate Period, 37-38 No. 23, pl. XIII (1), MFA 25. 679.

(n) A similar offering formula on stela of Nbjrf, see R. Engelbach, Steles and tables of offerings of the Late Middle Kingdom from Tell Edfu, in: ASAE 22, 1922, 113126.

(o) For the formula $3 h \mathrm{~h} W r \mathrm{~m} 3^{\mathrm{C}}-\mathrm{hr} w$, see W. Barta, Aufbau und Bedeutung der altägyptischen Opferformel, ÄF 24, 1968, 59 and 234, no. 7, and 65 and 237, no. 78 , no. 7 re-appears in the Twelfth Dynasty after an eclipse during the Ninth to Eleventh dynasty, no. 78 appears in the Twelfth Dynasty.

(p) hrt-ntr is attested on the inscriptions of the offering formula of Naga ed-Deir stelae. It occurs on ten stelae. Five instances are dating to the end of Old Kingdom and later, see Leprohon, Stelae I, MFA 25.676; Lutz, H.F., Egyptian Tomb Steles and Offering Stones, Leipzig 1927, pl. 10 no.19; pl. 19 no 37; pl. 22 no.42; pl.23 no.45. Three stelae are dating to the FIP, see Leprohon, Stelae I, MFA 25-674, 12.1475; Dunham, Nagaed-Deir, pl. XVI no.1 (53). Two stelae are dating to MK or earlier, see Leprohon, Stelae I, MFA 72.763; Lutz, Steles, pl. 28. no. 54.

(q) 3tw before was read $w^{\top} r t w$, see A. H. Gardiner, Egyptian Grammar, 1988, 560 , this is now read $3 t w$, see $\mathrm{R}$. Hannig, Ägyptisches Wörterbuch 2:

\section{References}

[1] Kuentz, Ch., (1928). Quelques monuments du culte de Sobk, in: BIFAO, Vol. 28, pp: 127-135; Helck, W., (1986). Sumenu, L̈̈, Lexikon der Ägyptologie, Wiesbaden, Vol. VI; Sauuneron, S., (1986) Quelques monuments de soumenou au Musée de Brooklyn, Kemi Vol. 18, pp: 71-72; Hodjash, S. \& Berlev, O., (1975). Several Middle Kingdom Stelae of the
Mittleres Reich und Zweite Zwischenzeit, 2006, 16; D. Jones, An Index of Ancient Egyptian Titles, Epithets and Phrases of the Old Kingdom I, Oxford 2000, 398-399; W. A. Ward, Index of Egyptian Administrative and Religious Titles of the Middle Kingdom and Related Subjects, Beirut 1986, 84.

(r) $P s \check{s}$ as a name appeared from the beginning of the Middle Kingdom, see Ranke, $P N$ I, 137.4.

(s) About $m 3$-hrw see R. Engelbach, "Steles and tables of offerings of the late Middle Kingdom from Tell Edfu", in: ASAE 22, 1922, 113-138.

(t) The text in this part is very damaged perhaps read [s3 $n$-----.ms $n$ ] 'Iwh-Ibw, probably the same name in: Lange/Schäfer, Grab- und Denksteine des Mittleren Reiches, CGC 20661, see Ranke, $P N$ I, 18.13.

(u) For this place, see: Montet, Géographie II, 152; Gomaa, Besiedlung, 312-318; Helck, Gaue, 76-77; Gauthier, Montet Dictionnaire des noms géographiques III, Cairo 1926, 99.

(v) 'nh-nb-sw-mnw is mentioned in Ranke as 'nh-nb.f, see Ranke, $P N \mathrm{I}, 64,26$.

(w) For the name Nbw-hr-hnyt cf. Ppy-hrhnyt, Ranke, $P N$ I, 132,8; Nbw-hr-hnyt Ranke,PN I, 191,22; Qwt-ḥr-hrr-hnnyt, Ranke, $P N$ I, 235,16; Mntw-hr-hnyt, Ranke, $P N$ II,290,9 (Old and Middle Kingdom).

(x) 'Iw.f-n.I-r-pšs, see Ranke, $P N$ I, 14,10 (Middle Kingdom).

(y) Nht.n.j, see: Ranke, $P N$ I, 207,13 (Middle Kingdom).

Moscow Fine Arts Museum, Altorientalische Forschungen Vol. 3, pp: 5-18; Bakry, H., (1971). The discovery of a Temple of Sobk in Upper Egypt, MDAIK, Vol. 27, pp: 131-149 ; Horst, B., (1992). Eine Stele des Nebseni und des Sobekmose von Er-Rizeikat, SAK Vol. 19, pp: 37-77; Montet, P., (1961). Géographie de l'Égypte Ancienne II, Paris; Gomaà, F., 
(1986). Die besiedlung Ägyptens während des mittleren reiches I: oberägypten und das Fayyūm, TAVO Beiheft B/66 [1], Wiesbaden, pp: 117-150; Helck, W., (1974). Die altägyptischen gaue, TAVO Beiheft B/5, Wiesbaden, pp: 76-77; Gauthier, H., (1928). Dictionnaire des noms géographiques, contenus dans les textes hiéroglyphiques /1-7; Vercoutter, J., (1957). Upper Egyptian settlers in Middle Kingdom Nubia (Stelae Khartoum Mus. 11778, 372 A and 2647, Statue Khartoum Mus. 5516), Kush Vol. 5, pp: 61-66; Morenz, L. \& Fitzenreiter, M., (2005). Die Sobeks- spuren von volksreligion im ägyptischen Mitteren Reich", IBAES Vol. 4, pp: 83-97; Javier, M., (2005). Ein Schwert aus der ersten Hälfte der 18 . Dynastie, GM Vol. 208, pp: 51-56; Selim H., (2001). Three identical Stelae from the end of the Twelfth or Thirteenth Dynasty, SAK Vol. 29 pp: 319-330; Maurer, K., (2000). Untersuchungen zum Krokodilskult von Sumenu, München; Beinlich, H., (1992). Eine Stele des nebsem und des Sobekmose von Er-Rizeikat, SAK, Vol. 19, pp: 37-77; Rosati,G.,
(2004). A group of Middle Kingdom stelae from el Rizeiqat-El Gebeelein, SAK, Vol. 32, pp: 333-349.

[2] Catalogue Général des Antiquités Egyptionnes du Musée du Caire, Kairo, 20144, 20145, 20160, 20282, 20398 from Abydos, CGC 20150 from Dra Abu el-Naga.

[3] Vernus, P. (1986). Le Surnom au Moyen Empire. Pontifical Biblical Institute, Rome.; Quirke, S. (1987). The regular titles of the late Middle Kingdom, RdE, Vol. 37, pp: 107-130.

[4] Ranke, H., (1935) Die ägyptischen Personennamen, Glückstadt, Vol. I, 137.4, 209.7, 14.10.

[5] Andrey, O., Stephen, B. \& Quirke, G. (1999). The Middle Kingdom Stelae in the Hermitage III, Paris, stela of $N b(w)-s w-m n . w, \quad$ from Abydos, pl s. 17, 23; Barta, W., (1968). Aufbau und Bedeutung der altägyptischen Opferformel, $\ddot{A F}$ Vol. 24, Vol. 32, pp: 52-56; Bennett, C., (1941); Growth of the htp-di-nsw formula in the Middle Kingdom, JEA Vol. 27, pp: 77-82; Smither, P., (1939). The writing of $h t p-d i-n s w$ in the Middle and New Kingdoms, JEA Vol. 25, pp: 34-37. 